DOI: 10.31866/2617-2674.4.1.2021.235059

UDC 070:303.62]:316.774

\title{
ISSUES OF THE INTERVIEW GENRE IN CONTEMPORARY MEDIA SPACE
}

\author{
Alla Medvedieva ${ }^{1 a}$, Serhii Chernenko ${ }^{2 b}$ \\ ${ }^{1}$ PhD in Art Studies, Associate Professor; \\ e-mail: aamedvedeva@i.ua; ORCID: 0000-0003-1422-7743 \\ ${ }^{2}$ Master's Student at the Cinema and Television Arts Department; \\ e-mail: azraildc13@gmail.com; ORCID: 0000-0002-3241-9362 \\ ${ }^{a}$ Kyiv National University of Culture and Arts, Kyiv, Ukraine \\ ${ }^{b}$ Kyiv University of Culture, Kyiv, Ukraine
}

\section{Keywords:}

interview;

television;

media;

interviewer

\begin{abstract}
The purpose of the research is to investigate the problems of the genre in modern media discourse. Research methodology. When writing a scientific article, research methods are used: analysis and synthesis (analyzed and systematized the work of the interview genre have been analyzed and systematized), a comparative method (parallels of interviews in the world and Ukraine have been made), generalization and systematization (summarizing has been made due to practical knowledge and work with diverse literature). Scientific novelty. This article is relevant today, despite the huge number of ready-made materials and articles. Scientific work will help to understand the essence of conducting one of the most complex genres of information journalism and will demonstrate the problems of interviews in Ukraine. Conclusions. During the study of the interview genre in the modern media space, the problems of the interview genre were analyzed through scientific works. It has been established that interviews are a special genre in modern media discourse that helps to reveal or create something completely new and show another angle of the interlocutor. Being one of the leading genres on television, the interview makes a significant contribution to the growth of popularity in a modern environment on the leading channels of the country. Psychological factors have been disclosed, which contribute to the success of communication with a guest; potential problems, the main difficulties faced by the interviewer have been outlined. It has been proved that during the conversation, important moments that turn into information are revealed. The fact that in modern information space, especially in Ukrainian media, there is a lack of qualification of leaders during interviews, is accentuated. Based on them, we summarized the main problems and features of the interview genre. As a result, while working with the article, we have made a conclusion about the main problems of the genre on modern television.
\end{abstract}

\section{For citation:}

Medvedieva, A. and Chernenko, S. (2021). Issues of the interview genre in contemporary media space. Bulletin of Kyiv National University of Culture and Arts. Series in Audiovisual Arts and Production, 4(1), pp.11-17. 


\section{Problem statement}

For the Ukrainian media space, studying this topic can help many TV journalists to raise their level of communication and achieve better interviews with participants. Analyzing the behaviour of Ukrainian presenters during the interviews, it should be noted that the general level of training is far from perfect, even on leading Ukrainian TV channels.

The purpose of the research is to analyze the problematics of the interview genre in the contemporary media world.

\section{Recent research and publications analysis}

We found the following published materials, books of various theorists and artists to write this article: L. King (1994), N. Babych (2017), D. Dutsyk (2012), V. Kulyk (2010), V. Spivak (2012), etc.

\section{Main material}

This scientific work can have several variations and affects the urgent problems of modern television. Thus, insufficient qualification of specialists affects the low quality of the finished product as a whole. On the basis of the American model of interviews, there is an opportunity to enter the global media space of the country and touch upon the main problem of the now-popular genre of television journalism.

While watching TV, you may notice how the moderator makes a number of mistakes that cannot be forgiven during the conversation: interrupts the interlocutor, listens inattentively, instead of simple and open questions asks sharp and inappropriate, because of which, the interview turns into "torture" for the invited guest, and for the host, the opportunity to demonstrate their "professional" qualities. In this field, it's called "to get to the bottom" or even harder "to have a hard talk". It is with this attitude that many journalists enter into a discussion with a guest (Dutsyk, 2012, p.115).

The approach to the interview on Larry King's show is radically different from the usual - the host does not use "sharp" and "uncomfortable" questions, but only listens carefully to the interlocutor and does not create an atmosphere of close questioning (Kulyk, 2010, p.55).

Ukrainian television, especially news, is based on negativity. Everything that is forbidden in the media is allowed (dissemination of state secrets, terrorism, crime and pornography).

V. Spivak singles out such potential problems during the interview:

- Inappropriate questions. There are no forbidden questions, but there are many questions that are inappropriate to ask. The main rule when interviewing: "Ask only those questions that are related to work!"

- Hasty judgments. Practice shows that interviewers often make judgments about candidates in the first few minutes of the interview. If this happens, the viewer is no longer so interested in the interview.

- Dominance of the interviewer. Due to the proper conduct of the interview, the relevant information should go in both directions. Therefore, interviewers need to be able to listen and present the information correctly.

- Inconsistent questions. If the facilitator asks everyone almost the same questions and in the same order, the opinion of the interviewees is formed from what the predecessor said.

- Central trend. Not all interviewees can be judged on average, as each is either weaker or stronger. 
- Halo error. You can't choose one person who can fail to communicate when talking to several people.

- Contrast effects. Looking at the interlocutor should not draw conclusions immediately, because the first impression may be wrong.

- Impartiality (prejudice) of the interviewer. Interviewers must be able to acknowledge their prejudices and learn to avoid them.

- Lack of training. Most interviewers do not have theoretical skills, as they do not have a television education.

- Conduct pattern. Even if the interviewer has spent a week with the interlocutor, the latter's behaviour may not provide enough material to properly assess his qualifications.

- Nonverbal communication. The interviewer should observe himself to avoid inappropriate or accidental nonverbal cues during the interview. (Spivak, 2012).

The purpose of the interview is to hold a conversation with outstanding personalities and experts in a certain field to spread their knowledge to a wide public. For example, a well-known politician, when speaking on some aspects of his party's policy, can clearly reveal himself as an individual during the interview. And if the presenter manages to show the interlocutor from the other side - it is a victory. And without problems cannot do. After all, if a TV journalist asks an inappropriate question during an interview, the interview can be considered a failure.

The psychological training of the interviewer also affects the problems that arise. If the journalist is not morally ready, the conversation may not take place at all. Now there are psychological factors that contribute to the success of communication with the guest:
- The first thing to do is to understand that most people are very chaotic. Therefore, when the presenter prepares for the interview, the behaviour should be the main model, and if this model does not work, turn on the backup option.

- The interviewer should be able to quickly adjust to working with the guest and respond normally to everything that happens on the air. The interviewer works both as an actor and a director, and each of his interviews is a small theatrical performance, a dialogue.

- The interviewer must be able to adjust to the behaviour of the interlocutor, as the mental state of the interlocutor is constantly changing, which in turn affects the end result of the conversation.

- Psychological training depends on how the facilitator has adjusted to the dialogue, at what time and in what place it takes place, in what he/she is dressed, and to what extent his/her image corresponds to his/her inner world. All this should create pleasant conditions that will help to reveal the guest. The interviewer must have professional voice skills and abilities. Every detail of clothing and even the tone of voice are important (Winterhoff-Spurk, 2007, p.71-73).

The most popular interviewer is Larry King. He has had many interviews in his professional career that he knows about television issues in this genre. Note that you should not be afraid to make mistakes, but you should as a result skillfully move away from them. In his book, King emphasizes, "Sometimes you have to tell a story from your own life to control your emotions and act as a mediator" (King, 1994, p.78). According to him, listeners love him for his style of "street issues" and the ability to be outside the discussed topic - this is what modern Ukrainian TV journalists lack (King, 1994, p.78). 
According to King, one of the reasons for his success is that he has always remained true to his journalistic principles: "I could be interpreted differently, but I always did the same thing - Who, what, when, where and why. I ask a question. We have in the studio Frank Sinatra, the most famous man in the world. I am sitting opposite him. The light comes on, and I say, "Welcome to the Larry King Show." Frank Sinatra is visiting me today. What brought you here?" I did not carry all sorts of nonsense like "this is my old friend" (King, 2012, p.32).

$\mathrm{N}$. Babych identifies the following main shortcomings of the interviewer's work:

1. Stressfulness (among the most stressful professions, the profession of TV journalist takes 3rd place). This degree is determined by the number of heart attacks, diseases, accidents, divorces.

2. Interviewer's profession depends on the degree of talent.

3. Infinite self-improvement of talent. It does not have the ultimate level of skill. A TV journalist always learns (reads, learns languages, improves his style). Working on television is a certain way of life that people always do.

4. The art of constant communication. The presenter must have professional didactics.

5. Attitude to versatility. All-knowing interviewer (Babych, 2017, p.65).

It is not possible to minimize mistakes and problems during the interview, but there are a number of factors that can help a TV journalist.

- The facilitator should prepare carefully for the interview. First, you need to formulate the topic and problem, as well as introduce the guest, so as not to force the viewer to spend time and effort to understand what we are talking about.

-When preparing questions, it is necessary to reveal the problem and ways to solve it and maintain the interest of the audience. Therefore, a TV journalist needs to understand for himself what he wants to achieve from talking to a guest in the studio.

- After asking a question, you should wait for the beginning of the answer and only then be distracted from writing for a couple of seconds. Otherwise, the interlocutor will get the impression that no one needs the answer of the interviewee and as a result, the interview will fail.

- Conversation means not being an interrogator or a chat.

- The journalist should be free and attentive to the interlocutor, react to changes in the situation during the conversation.

- Develop tactics of interviewing: a combination of different questions, their alternation, sequence, the rhythm of conversation.

- Exclusive interviews are more productive than public ones (they can say what they don't say in general).

- Asking questions, noticing gaps or inconsistencies in the answers is an important task for the interviewer, even at the cost of being annoying or annoying at times.

- You should learn to sum up at the end of the interview. This will help the viewer to understand what follows from the material (Babych, 2017, p.87-89).

Analyzing the issues of the interview genre in the modern media space, many different projects have been analyzed to understand how interviewers work. Compared to Russian or American media projects, there are far fewer problems in Ukraine.

Among the analyzed presenters, the most problematic interviewers were: Matvii Hanapolskyi "Direct" and Serhii Prytula "New Channel", "STB". 
In his interviews, Matvii Hanapolskyi puts pressure on his interlocutor and may even say a "sharp" word that is not professionally spoken on the air. The host puts his opinion above what his guest says. He has worked for many Russian TV channels and has been working in Ukraine for the past few years. Hanapolskyi is one of those interviewers who got into a scandal live because he said he did not like the President of Ukraine, Volodymyr Zelenskyi. Despite this, he continues to create new stories around himself. Analyzing his work, it should be noted that this is an already developed style of work, but psychological and incorrect communication with guests creates a negative perception and compromises him as a non-professional TV journalist.

The presenter should not impose, he should help the viewer to come to the right opinion on their own.

Given the above, we conclude that this analysis makes it clear that not many Ukrainian interviewers have problems or get into scandalous situations. People who work in television have no professional education, and knowledge of theoretical material is no less important than practical.

\section{Conclusions}

Based on the above, we've concluded that the interview is a special genre in modern media discourse, which helps to reveal or create something completely new and show a different perspective of the interlocutor. The preparation process is no less problematic than the interview itself, but still more interesting. It is proved that during the conversation important points are revealed, which turn into information. The presenter must be able to get out of any situation, especially if he created it himself.

In general, in the modern information space, especially in the Ukrainian media, there is a lack of qualifications of presenters during interviews. If we analyze the specifics of the conversation with the respondent, we can see that most of the questions are built on the principle of premature judgments, which in turn leads to the effect of information. This usually occurs when the interviewer is deeply acquainted with the evaluative judgments and general opinions about the interlocutor, especially when it comes to a public figure. As a result, the presenter has a certain attitude, which significantly reduces the veracity of the information obtained.

After examining the materials on the above topic, we came to the conclusion that Ukrainian interviewers and interviews, in general, have fewer problems than in other countries. After all, our television is just beginning its main development and formation, so everyone is trying to work according to a certain scenario. Scandals are usually present, but they are fleeting.

An analysis of the interview genre allows us to draw the following conclusions. The first questions of all interviews perform their main function - to intrigue the audience. However, questions in the first and second groups are more effective because they reduce the distance between the interviewer and the interviewee. This allows the TV journalist to successfully reveal the image of the invited guest. Interview, being one of the leading genres on television, makes a significant contribution to the growth of popularity in today's environment on the country's leading channels. 


\title{
REFERENCES
}

Babych, N.D. and Zhuk, O., 2017. Problemy kultury movy i stylistyky v zhurnalistskii praktytsi [Problems of language culture and stylistics in journalistic practice]. Chernivtsi: Ruta

Dutsyk, D.R., 2012. "Mova vorozhnechi" v dyskursi ukrainskykh media ["Hate speech" in the discourse of the Ukrainian media]. Suchasni suspilni problemy u vymiri sotsiolohii upravlinnia. Seriia "Sotsiolohiia", XIII, 217, p.118.

King, L., 1994. Kak razgovarivat s kem ugodno, kogda ugodno i gde ugodno [How to Talk to Anyone, Anytime, Anywhere]. Moscow: Alpina Pablisher.

King, L., 2012. Po pravde govoria [In truth]. Moscow: Astrel.

Kulyk, V., 2010. Dyskurs ukrainskykh media: identychnosti, ideolohii, vlasni stosunky [The discourse of the Ukrainian media: identities, ideologies, own relations]. Kyiv: Krytyka.

Spivak, V.A., 2012. Upravlenie personalom dlia menedzherov [Human resource management for managers]. [online] Available at: <https://www.twirpx.com/file/1033716/> [Accessed 28 April 2020].

Vinterkhoff-Shpurk, P., 2007. Mediapsikhologiia. Osnovnye printcipy [Mediapsychology. Basic principles]. Kharkov: Gumanitarnyi tcentr.

\section{ПРОБЛЕМАТИКА ЖАНРУ ІНТЕРВ'Ю В СУЧАСНОМУ МЕДІЙНОМУ ПРОСТОРІ}

\section{Алла Медведєва ${ }^{1 a}$, Сергій Черненко ${ }^{2 b}$}

\author{
${ }^{1}$ кандидат мистецтвознавства, доцент; \\ e-mail: aamedvedeva@i.ua; ORCID: 0000-0003-1422-7743; \\ ${ }^{2}$ магістрант кафедри кіно-, телемистецтва; \\ e-mail: azraildc13@gmail.com; ORCID: 0000-0002-3241-9362 \\ а Київський національний університет культури і мистецтв, Київ, Україна

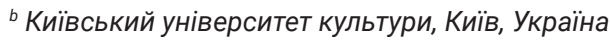

\section{Анотація}

Мета дослідження - дослідити проблематику жанру інтерв'ю в сучасному медійному дискурсі. Методологія дослідження. Під час написання наукової статті використані методи дослідження: аналіз та синтез (проаналізовано та систематизовано роботу жанру інтерв'ю), порівняльний метод (проведено паралелі роботи інтерв'ю у світі та Україні), узагальнення та систематизація (підведено підсумки завдяки практичним знанням та роботі з різноманітною літературою). Наукова новизна. Дана робота має актуальність на сьогодні, попри величезну кількість вже готових матеріалів і статей. Наукова робота допоможе зрозуміти суть проведення одного з найскладніших жанрів інформаційної журналістики та продемонструє проблеми інтерв'ю в Україні. Висновки. Під час дослідження було проаналізовано проблематику жанру інтерв'ю. Встановлено, що інтерв'ю - це особливий жанр в сучасному медійному дискурсі, який допомагає розкрити або створити щось зовсім нове та показати інший ракурс співрозмовника. Бувши одним з провідних жанрів на телебаченні, інтерв'ю вносить значний внесок в зростання популярності в сучасному середовищі на провідних каналах країни. Розкрито психологічні чинники, що сприяють успіху спілкування з гостем; 
окреслено потенційні проблеми, головні труднощі, з якими стикається інтерв'юер. Доведено, що під час бесіди розкриваються важливі моменти, які перетворюються на інформацію. Акцентовано на тому, що в сучасному інформаційному просторі, особливо в українських медіа, простежується недостатня кваліфікованість ведучих при проведенні інтерв'ю.

Ключові слова: інтерв'ю; телебачення; медіа; інтерв'юер

\title{
ПРОБЛЕМАТИКА ЖАНРА ИНТЕРВЬЮ В СОВРЕМЕННОМ МЕДИЙНОМ ПРОСТРАНСТВЕ
}

\author{
Алла Медведева ${ }^{1 a}$, Сергей Черненко $2 \mathrm{a}$ \\ ${ }^{1}$ кандидат искусствоведения, доцент; \\ e-mail: aamedvedeva@i.ua; ORCID: 0000-0003-1422-7743 \\ 2 магистрант кафедры кино-, телеискусства; \\ e-mail: azraildc13@gmail.com; ORCID: 0000-0002-3241-9362 \\ а Киевский национальный университет культуры и искусств, Киев, Украина

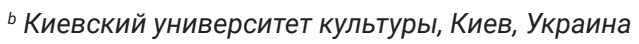

\begin{abstract}
Аннотация
Цель исследования - изучить проблематику жанра интервью в современном медийном дискурсе. Методология исследования. При написании научной статьи использованы методы исследования: анализ и синтез (проанализирована и систематизирована работа жанра интервью), сравнительный метод (проведены параллели работы интервью в мире и Украине), обобщения и систематизация (подведены итоги благодаря практическим знаниям и работе с разнообразной литературой). Научная новизна. Данная работа имеет актуальность на сегодня, несмотря на огромное количество уже готовых материалов и статей. Научная работа поможет понять суть проведения одного из самых сложных жанров информационной журналистики и продемонстрирует проблемы интервью в Украине. Выводы. В ходе исследования была проанализирована проблематика жанра интервью. Установлено, что интервью - это особый жанр в современном медийном дискурсе, который помогает раскрыть или создать нечто совершенно новое и показать другой ракурс собеседника. Будучи одним из ведущих жанров на телевидении, интервью вносит значительный вклад в рост популярности в современной среде на ведущих каналах страны. Раскрыты психологические факторы, способствующие успеху общения с гостем; обозначены потенциальные проблемы, главные трудности, с которыми сталкивается интервьюер. Доказано, что во время беседы раскрываются важные моменты, которые превращаются в информацию. Акцентировано на том, что в современном информационном пространстве, особенно в украинских медиа, прослеживается недостаточная квалификация ведущих при проведении интервью.
\end{abstract}

Ключевые слова: интервью; телевидение; медиа; интервьюер 